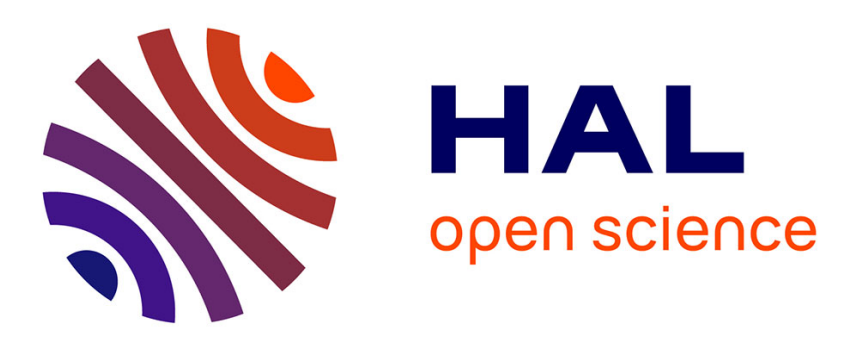

\title{
Interfacial and foaming properties of two types of total proteose-peptone fractions
}

\author{
Gaoussou Karamoko, Sabine Danthine, Gilles Olive, Christophe Blecker
}

\section{To cite this version:}

Gaoussou Karamoko, Sabine Danthine, Gilles Olive, Christophe Blecker. Interfacial and foaming properties of two types of total proteose-peptone fractions. Food and Bioprocess Technology, 2013, 6 (8), pp.1944-1952. 10.1007/s11947-012-0916-4 . hal-00724542

\section{HAL Id: hal-00724542 \\ https://hal.science/hal-00724542}

Submitted on 21 Aug 2012

HAL is a multi-disciplinary open access archive for the deposit and dissemination of scientific research documents, whether they are published or not. The documents may come from teaching and research institutions in France or abroad, or from public or private research centers.
L'archive ouverte pluridisciplinaire HAL, est destinée au dépôt et à la diffusion de documents scientifiques de niveau recherche, publiés ou non, émanant des établissements d'enseignement et de recherche français ou étrangers, des laboratoires publics ou privés. 


\section{Food and Bioprocess Technology: An International Journal INTERFACIAL AND FOAMING PROPERTIES OF TWO TYPES OF TOTAL PROTEOSE-PEPTONE FRACTIONS

\author{
--Manuscript Draft--
}

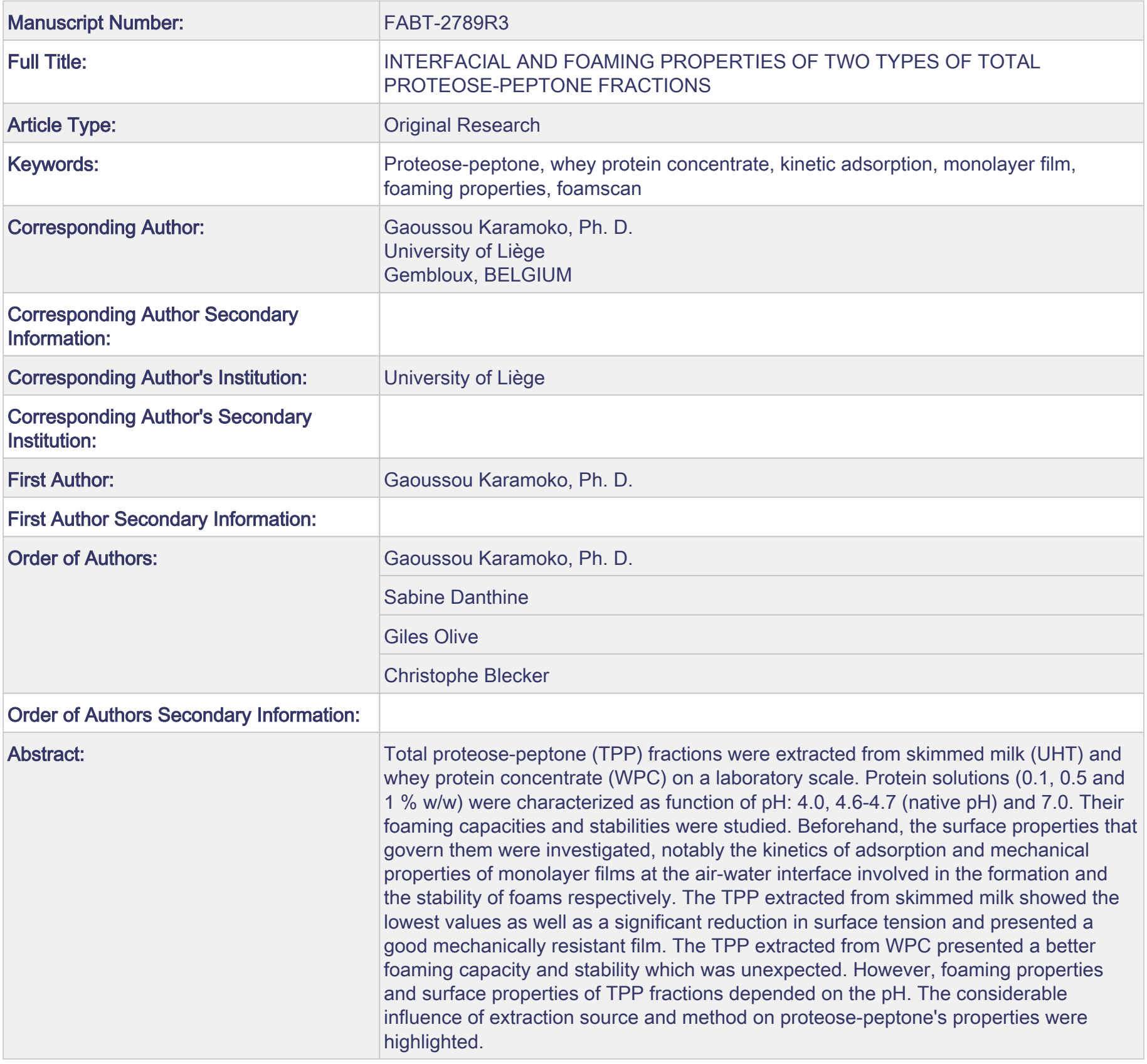


1

2

3

4

5 University of Liege, Gembloux Agro-Bio Tech, Department of Food Sciences and

6 Formulation, Passage des Déportés 2, B-5030 Gembloux, Belgium.

$7 \quad *$ Corresponding author. Tel: +3281622564 ; fax: +3281601767 .

$8 \quad$ E-mail adresse: karamgao@yahoo.fr 


\section{Abstract}

Total proteose-peptone (TPP) fractions were extracted from skimmed milk (UHT) and whey protein concentrate (WPC) on a laboratory scale. Protein solutions $(0.1,0.5$ and $1 \%$ w/w) were characterized as function of $\mathrm{pH}$ : 4.0, 4.6-4.7 (native $\mathrm{pH}$ ) and 7.0. Their foaming capacities and stabilities were studied. Beforehand, the surface properties that govern them were investigated, notably the kinetics of adsorption and mechanical properties of monolayer films at the air-water interface involved in the formation and the stability of foams respectively. The TPP extracted from skimmed milk showed the lowest values as well as a significant reduction in surface tension and presented a good mechanically resistant film. The TPP extracted from WPC presented a better foaming capacity and stability which was unexpected. However, foaming properties and surface properties of TPP fractions depended on the $\mathrm{pH}$. The considerable influence of extraction source and method on proteose-peptone's properties were highlighted.

Keywords: Proteose-peptone, whey protein concentrate, kinetic adsorption, monolayer film, foaming properties, foamscan 


\section{Introduction}

Foams are a subject of strong interest in a large number of industries where they play a crucial role. In the food industry, a foaming formulation involves the use of surface-active agents. During the foaming processes, these agents adsorb rapidly and form a film at the surface of gas bubbles. Surface-active agents must simultaneously give abundant and stable foams. Many researches are focused on the development of novel ingredients, including proteins which can be used as foaming agents. Food processing industries use these protein ingredients to improve the functional properties of a wide range of formulated food (Cassiani et al., 2011). Among food proteins, whey proteins are considered as important and valuable ingredients due to their high nutritional and functional properties (Blecker et al., 1997; Mladen et al., 2009). These features confer to whey proteins ingredients high foaming and stabilizing properties.

Among the whey components the total proteose-peptone fraction (TPP) could be of interest. Indeed the TPP is a minor fraction of the heat-stable and acid-soluble protein which is found in whey (Blecker et al., 2005). According to the literature, this fraction has interesting functionalities such as surface properties, emulsifying properties and foaming properties (Shimizu et al., 1989; Innocente et al., 1998a, 1998b).

However, previous works on the foaming property of the milk's TPP fraction are controversial. Some authors such as Zhu and Damodaran (1994) have shown a negative effect of the TPP on the foam property (foam stability) produced by whey due to certain competitive actions of other proteins. On the other hand, the TPP fraction is considered responsible of milk foaming capacity due to its component PP3 (Girardet and Linden, 1995). Moreover, most of studies reported in the literature concerns the TPP extracted from milk. 
In the light of these considerations, this study attempted to provide new information

about the foaming properties of TPP, especially the TPP extracted from whey. To reach this goal, two types of TPP fractions were extracted in this work. The first one was extracted from skimmed milk using a classic method according to Pâquet et al (1988) and the second was extracted from whey protein concentrate according to a procedure which is feasable on an industrial scale.

The interest of this work is to study the TPP extracted from whey protein concentrate (78\% of protein), a commercially available by-product of cheese processing. The use of this alternative source could allow an increased TPP production for industrial applications. Foam properties were characterized for possible use in food applications requiring foam formation such as whipped cream, ice cream, cakes and desserts.

In the literature, SDS-PAGE electrophoresis was used to characterize the TPP fraction's components according to Laemmli's method (Pâquet et al., 1988). However several others separation techniques were also used including liquid chromatography which allow a good separation of the TPP's components. The hydrophobic interaction was most often used to separate the TPP due to the hydrophobicity of some major components. In our case, Tricine SDS-PAGE electrophoresis according to schägger (2006) was used to characterize the TPP, due to it's high resolution, especially for the small proteins.

The aim of this study was to determine the ability of TPP fractions to form and stabilize foams at several protein concentrations, at various $\mathrm{pH}$, and to highlight the influence of the extraction method on these properties. 


\section{Materials and methods}

\subsection{Extraction of total proteose-peptone fractions}

\subsubsection{Extraction from milk}

Milk total proteose-peptone fraction (milk TPP) was extracted from UHT skimmed milk according to the procedure described by Pâquet et al. (1988) with some modifications. Three batches of ten litres of commercial skimmed milk (Everyday, Colruyt, Belgium) were used to extract the TPP. The process consisted in heating one litre of skimmed milk at $90-95{ }^{\circ} \mathrm{C}$ during 30 min and then cooling it down in an ice bath to $20{ }^{\circ} \mathrm{C}$ during $40 \mathrm{~min}$. $\mathrm{pH}$ was then adjusted at 4.6 with $1 \mathrm{M} \mathrm{HCl}$ to induce isoelectric precipitation. Samples were centrifuged at $5000 \mathrm{~g}$ for $30 \mathrm{~min}$ at $20{ }^{\circ} \mathrm{C}$ (Centrifuge Beckman Model J2-21, Indianapolis, USA). Ammonium sulfate $(304 \mathrm{~g})$ was added to the supernatant $(800 \mathrm{~mL})$ to obtain a half-saturated solution that was then shaked and centrifuged $\left(5000 \mathrm{~g}\right.$ for $10 \mathrm{~min}$ at $\left.20{ }^{\circ} \mathrm{C}\right)$. The pellet was dispersed, exhaustively dialyzed and finally lyophilized. The TPP yield was stored at $4{ }^{\circ} \mathrm{C}$ until analysis.

\subsubsection{Extraction from whey protein concentrate (WPC)}

Whey protein concentrate (WPC) (Lacprodan 80) was obtained from Arla Foods Ingredients (Viby J, Denmark). $2.85 \mathrm{Kg}$ of commercial WPC were used. WPC was dispersed into distilled water (95 g.L $\mathrm{L}^{-1}$ ) by stirring at room temperature for 2 hours to ensure good dispersion. Whey total proteose-peptone (WPC TPP) was then extracted from the dispersion using the same procedure described for extraction from milk without the ammonium sulfate addition. The TPP yield was stored at $4{ }^{\circ} \mathrm{C}$ until analysis.

\subsection{Chemical composition of TPP}


The TPP fractions obtained were analyzed for ash (AOACI, 2000), lipid by modified mojonnier method (AOACI, 2000) and lactose (Miller, 1959). The determination of protein content was performed by the Lowry method as described by Lowry et al. (1951).

\subsection{Electrophoretic Analysis using Tricine-SDS-PAGE}

TPP molecular weight distribution was evaluated by Tricine-SDS-PAGE electrophoresis following the method of Schägger (2006). The Tricine-SDS-PAGE was performed with a vertical electrophoresis apparatus model 2001 (Amersham-Pharmacia, Uppsala, Sweden) with a $16 \%$ polyacrylamide separating gel $(16 \% \mathrm{~T}, 3 \% \mathrm{C}$ where $\mathrm{T}$ is the total concentration of acrylamide/bis-acrylamide monomers and $\mathrm{C}$ is the amount of crosslinker relative to the total concentration) and thickness of $1.5 \mathrm{~mm}$. Tricine-SDS-Page uses two buffers and offers a high resolution, especially in the small protein and peptide range. The electrophoresis buffers were tris- $\mathrm{HCl}$ buffer (anode buffer) and Tricine-tris buffer (cathode buffer). $500 \mu \mathrm{l}$ of sample $(1-3 \% \mathrm{w} / \mathrm{v}$ of proteins) were treated with a equivalent volume of sample buffer (150 mM Tris- $\mathrm{HCl}, \mathrm{pH} 7.0,12 \%$ SDS; $6 \%$ mercaptoethanol, $30 \%$ glycerol, $0.05 \%$ Coomassie blue), and then heated at $37{ }^{\circ} \mathrm{C}$ for $15 \mathrm{~min}$ before electrophoresis. Electrophoresis was performed at an initial voltage of $30 \mathrm{~V}$ for stacking and at a constant voltage of $90 \mathrm{~V}$ for separation. The protein bands were fixed in a solution consisting of $50 \%$ methanol, $10 \%$ acetic acid, and $100 \mathrm{mM}$ ammonium acetate for $60 \mathrm{~min}$, before staining by $0.025 \%$ coomassie dye in $10 \%$ acetic acid for $24 \mathrm{~h}$. The gel destaining was performed in 10 $\%$ acetic acid.

\subsection{Dynamic Drop Volume Method}

TPP samples were prepared in ultra-pure water (ultra-pure water system Milli.Q50, Millipore). TPP solutions of $0.1,0.5$ and $1 \%(\mathrm{w} / \mathrm{w})$ were prepared at various $\mathrm{pH}$ values: 4.0, 4.6-4.7 (native $\mathrm{pH}$ ) and 7.0. Automated drop volume tensiometer TVT1 (LAUDA, Königshöfen, Germany) was used to perform dynamic measurements for surface tension 
measurements at air-water interface. The experiments resulted in the measurement of surface tension as a function of the drop formation time (Innocente et al. 1998). All experiments were performed at $25 \pm 0.5^{\circ} \mathrm{C}$. Each measurement was repeated three times. Equilibrium interfacial tension $\left(\gamma_{\mathrm{e}}\right)$ and the initial adsorption rate (v) were determined by extrapolated values of $\gamma$ vs. $\mathrm{t}^{-1 / 2}$ at $\mathrm{t} \rightarrow \infty$ and the tension $(\gamma)$ versus time $(\mathrm{t})$ curve slope at initial time $\left(\mathrm{t}_{0}\right)$, respectively (Blecker et al., 2002; Innocente et al., 2011).

\subsection{Adsorption Kinetics Recording}

The surface tension-time dependence of TPP solutions was measured with the

\subsection{Mechanical properties of monolayer film}

Protein samples were prepared by dissolving the lyophilized material in ultra-pure water (ultra-pure water system Milli.Q50, Millipore). Protein solution (1 mg.mL ${ }^{-1}$ ) were characterized at various $\mathrm{pH}$ values: 4.0, 4.6-4.7 (native $\mathrm{pH}$ ) and 7.0. Measurements of the surface pressure $(\pi)$ versus surface area were performed on Langmuir-type film balance LFW2 (LAUDA GmbH, Königshöfen, Germany) of which the principle and the experimental condition were described by Innocente et al. (1998). Schematically this technique involved the measurement of the surface tension of an aqueous surface under different compression conditions in the presence and absence of a surface monolayer, and may be described by the following equation:

$$
\pi=\gamma_{0}-\gamma,
$$

where $\pi$ is the surface pressure, $\gamma_{0}$ and $\gamma$ are the surface tension of the clean surface and the surface containing the monolayer, respectively. The elasticity $(\varepsilon)$ of the protein film at the air- 
water interface, defined as the variation in surface pressure for a variation in the surface unit area, was then calculated for every point of the isotherm $\pi / \mathrm{A}$ by means of the following equation:

$$
\varepsilon=-\mathrm{A}(\mathrm{d} \pi / \mathrm{dA})
$$

147 where $\mathrm{d} \pi / \mathrm{dA}$ is the surface pressure derivative in surface area (Damodaran, 1994). All 148 experiments were performed at $25 \pm 0.5^{\circ} \mathrm{C}$.

\section{$149 \quad$ 1.7. Foaming properties}

$$
\mathrm{FC}=\mathrm{V}_{\mathrm{f}} / \mathrm{V}_{\mathrm{g}}
$$

Where $V_{f}$ is the final foam volume and is $V_{g}$ the final gas volume injected. Foam stability (FS) was determined as the time needed to drop to half the final foam volume $\left(\mathrm{T}_{1 / 2}\right)$.

Measurements were performed in triplicate with fresh solution. Protein solutions were prepared according to the sample preparation of the surface tension study. The speed of decreasing $(\mathrm{Sd})$ after switching off the bubbling was calculated using equation 4 .

$$
\left(\mathrm{FV}_{450 \mathrm{~s}}-\mathrm{FV}_{60 \mathrm{~s}}\right) /(450-60)
$$


$\mathrm{Sd}=$

60

\subsection{Statistical analysis}

The data shown are the average of triplicate values. Statistical analyses were carried out using a SPSS for windows, version 11.0 (SPSS Inc., 1999). The data were subjected to analysis of variance (ANOVA) using the general linear model option (DUNCAN test) to determine significant differences between samples $(\mathrm{P}<0.05)$.

\section{Resultats and Discussion}

Total proteose-peptone (TPP) fraction is usually extracted from milk, with a yield

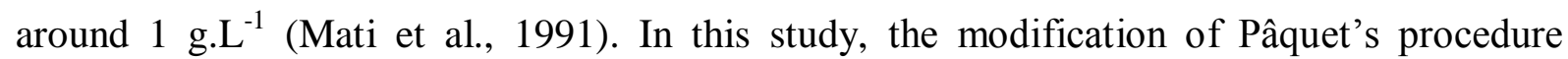
allowed to increase the quantity of TPP extracted from milk to 1.56 g.L $\mathrm{L}^{-1}$ of milk (i.e. $1.56 \mathrm{~g} /$ $130 \mathrm{~g}$ dry matter). The extraction of TPP from the alternative source WPC (78 \% of protein) reached $19.13 \mathrm{~g} / 95 \mathrm{~g}$ of WPC. The use of WPC allowed to increase the TPP production by a process potentially transposable on an industrial scale. However, the composition of TPP fractions (Table 1) showed a fundamental difference between the two types of TPP in terms of protein content. Milk TPP contains more protein than WPC TPP $(79.15 \%$ versus $65.20 \%$ of protein). The lipid content of milk TPP was relatively greater than in WPC TPP, while the 184 lactose content was more important in WPC TPP than milk TPP. It should be noted that 185 lactose represents a big part of nonprotein component that does not affect the interfacial 186 properties of the extract but could instead affect the foam stability (Zhu and Damodaron, 187 1994).

The protein analysis on milk TPP by Tricine SDS-PAGE (Figure 1), presented the same 189 bands as described in the literature, notably component PP3 also named LP28 (28 kDa) 190 according to (Kanno, 1989), LP18 (high hydrophobic component of $18 \mathrm{kDa}$ ) (Sorensen and 
191 Petersen, 1993), component PP5 (14.3 kDa) (Kollar and Brunner., 1970) and component 192 PP8S (9.9 kDa) (Kollar and Brunner., 1970). The band corresponding to component PP8 F as 193 referred to by Kollar and Brunner (1970) was not observed on the gel due to its very low 194 molecular weight $(4 \mathrm{kDa})$. The LP18 $(18 \mathrm{kDa})$ was the high hydrophobic component of the 195 FHPP of TPP. LP18 hydrolyzed by plasmin from LP28 in milk was absent in the extract of 196 WPC (WPC TPP). However, a difference in thickness and intensity was observed with regard 197 to the bands PP5 and PP3. Thus, the PP3 band in milk TPP appears stronger and more intense 198 than the PP3 band in WPC TPP. The PP5 band was thinner in milk TPP than WPC TPP. In 199 view of these observations, it could be said that milk contained more PP3 and less PP5 200 compared to WPC TPP, this depends on milk's evolution before undergoing heat treatments 201 such as UHT or whey processing.

\subsection{Dynamic surface tension}

Adsorption kinetics at the air-water interface of TPP fractions extracted from skimmed milk and WPC were compared by using dynamic surface tension technique. Many factors may affect this property at the interface such as concentration, $\mathrm{pH}$, and temperature. Among these, the concentration and $\mathrm{pH}$ were specifically considered. Therefore, Figure 2 represents 207 the surface tension as a function of drop formation time for both different fractions at $1 \%$ $208(\mathrm{w} / \mathrm{w})$, and at various $\mathrm{pH}$. Surface tension value decrease with the increase in drop formation 209 time, because molecules have more time to position themselves uniformly at the interface 210 where they can develop their surfactant activity (Innocente et al., 2011). At all tested 211 concentrations and $\mathrm{pH}$, the surface tension reduction was more pronounced for milk TPP in 212 comparison to WPC TPP. This suggested that milk TPP had a higher surface activity than 213 those extracted from WPC. This difference in behavior could be related to the hydrophobic 214 fraction commonly called HFPP which contains LP18 and LP28 in milk TPP according to the 
electrophoresis. Moreover, it was demonstrated that the surface-active properties of the TPP fractions are in part governed by the physicochemical properties of PP3 such as aggregation properties and surface hydrophobicity (Innocente et al., 1998a; Piquet et al., 1988). Therefore, the relative percentage of PP3 in each fraction might certainly explain the lower interfacial activity of WPC TPP compared to milk TPP.

The discussions hereafter are focused on the $1 \%(\mathrm{w} / \mathrm{w})$ solutions because the difference between the samples was not significant at $0.1 \%$ and $0.5 \%$ (P $\square 0.05$ ). It appeared that the milk TPP lowered the surface tension when the $\mathrm{pH}$ increased. Conversely, for WPC TPP the lowest value of surface tension was observed at $\mathrm{pH} 4.0$ or native $\mathrm{pH}$ (4.7). These composition could be at the origin of these behaviors with regards to $\mathrm{pH}$. Indeed, LP18 comprises four isolectric isoforms (pI 5.0 - 8.0) (Inagaki et al., 2010). At pH 7.0 milk TPP presented a net charge because this $\mathrm{pH}$ is in this range, which explained the lowest surface tension value at $\mathrm{pH}$ 7.0. Whereas, the $\mathrm{pI}$ of TPP is 4.0 to 5.0 according to Pâquet et al. (1988). So, WPC TPP presented a net charge at $\mathrm{pH} 4.0$ and native $\mathrm{pH}$ (4.70), which explained the lowest surface tension values obtained at these $\mathrm{pH}$ compared to $\mathrm{pH}$ 7.0.

The analysis of adsorption kinetic curves was quantified by determining the initial adsorption rate and equilibrium surface pressure (Table 2) to explain the reduction of surface tension. Thus, the initial adsorption rate is equivalent to the slope of the tangent to the curve at the start of the kinetics; it characterizes the velocity at which molecules lower the surface tension at the beginning adsorption. This initial adsorption rate has been determined using the automatic drop tensiometer tracker (Table 2) which was used as a complement to TVT. The initial surface tension value at $t=0$ corresponding to the water surface tension, was equal to $72.00 \mathrm{mN} . \mathrm{m}^{-1}$. Equilibrium surface pressure value $\left(\pi_{\mathrm{e}}=\gamma_{0}-\gamma_{\mathrm{e}}\right.$, where $\gamma_{0}$ is the initial surface tension and $\gamma_{\mathrm{e}}$ is the equilibrium surface tension) characterizes the maximum reduction of 

3

surface tension induced by the surfactant molecules, in our case the dispersion of the proteose-peptone. The highest values of initial adsorption rate and equilibrium surface pressure were observed for milk TPP $(\mathrm{P}<0.05)$. Equilibrium pressure values obtained correspond to a reduction of the initial surface tension value of 32 to $35 \%$ for milk TPP and 29 to $30 \%$ for WPC TPP. This indicated that milk TPP caused a rapid reduction of interfacial tension that reached the equilibrium values faster compared to WPC TPP. Many authors have shown that the adsorption rate is correlated with the foaming capacity of proteins (German et al., 1985; Dagorn-Scaviner, 1986) and the development of an important surface pressure is required to obtain good stability of dispersed systems (Nakai et al., 1980). Overall, these findings suggested a better foaming capacity for milk TPP compared to WPC TPP.

\subsection{Study of monolayer films}

Mechanical properties of the monolayer films formed by TPP fractions were investigated in addition to the adsorption kinetics study. This was done using a Langmuir film balance to determine the compression isotherms in order to understand the foaming properties. The compression isotherms obtained at the air-water interface represent the surface pressure against surface area (square meter per milligram of proteins). During the compression of film, the surface pressure increases.

In generally, when the film molecules undergo a compression, the surface area occupied per $\mathrm{mg}$ of protein decreases. The surface pressure increased from a value $\mathrm{A}_{0}$ (initial area), linearly up to a transition zone which was observed around an inflection point. After this, the surface pressure increased to a maximum value at the end of compression. Milk TPP formed films with a higher mechanical resistance with regard to surface pressure, compared to WPC TPP. The compression isotherms were recorded at different $\mathrm{pH}$, it is clear from Figure 3 that they present the same profiles at the considered $\mathrm{pH}$. The surface pressure changed with the 
pH. Monolayer films of milk TPP presented a better resistance at $\mathrm{pH} 7.0$ than at $\mathrm{pH} 4.0$, and inversely for the WPC TPP $(\mathrm{P}<0.05)$. These results are in agreement with those of the kinetics of adsorption at air-water interface.

The compression isotherms reflect the mechanical properties of the monolayer whereas 268 the stability of the film is a phenomenon linked to the forces of cohesion in the monolayer as

\subsection{Foaming properties}


Foam capacities (FC) of proteose-peptone fractions at $1 \%(\mathrm{w} / \mathrm{w})$ were compared at various $\mathrm{pH}$ as depicted in Figure 4. Generally, the foaming capacity increased with increasing concentration of protein. The foaming capacity of milk TPP was lower than that of WPC TPP at all $\mathrm{pH}$ studied. The milk TPP foaming power increased with the increasing of $\mathrm{pH}$, whereas the WPC TPP foaming power decreased with increasing $\mathrm{pH}$. This effect of $\mathrm{pH}$ on foaming capacity of each fraction was correlated with the adsorption rate obtained for each fraction (see paragraph 2.1). This is in accordance with German et al (1985) and Dagorn-Scaviner (1986) which showed a correlation between the adsorption rate and the foaming capacity.

The foaming inability of milk TPP can be explained by the quantity of fat in its composition. The quantity of lipid is greater in milk TPP than in WPC TPP (Table 1). The 297 presence of small lipid quantities can have a strong destabilizing effect on foaming (Huppertz, 2010). A lower FC of milk TPP induced a collapse of the air bubble during foam formation. This is probably due to the weak mechanical strengh of the lipid-protein interaction.

Foam stability (FS) was characterized by the half-life of foam volume. The effect of $\mathrm{pH}$ on this parameter is represented in Figure 5. As in the case of foaming capacity, the effect of $\mathrm{pH}$ on foam stability was correlated with the surface pressure obtained in Adsorption kinetics study. This was mentioned by Nakai et al. (1980) which say that the development of an important surface pressure lead to a good stability of dispersed systems.

In general, the increasing concentration of TPP improved foam stability (data not shown). WPC TPP capacity to stabilize foam was greater compared to milk TPP (at all $\mathrm{pH}$ ), as the time needed to reduce the foam volume to half of the maximum volume $\left(\mathrm{T}_{1 / 2}\right)$ was higher. This indicates the higher resistance of WPC TPP film to the coalescence of bubbles. The evolution of foam volume of TPP fraction at $1 \%$ during the first 450 seconds as function of $\mathrm{pH}$ is represented in Figure 6. The difference in foam behavior was demonstrated by the speed of decrease after switching off the bubbling (Table 4). The highest value of decrease 
312

speed was observed for milk TPP foam; this indicated a greater ability to stabilize for WPC 313 TPP. The better foaming properties of WPC TPP were essentially due to the lower quantities 314 of lipids in WPC TPP composition, as it is well known that lipids destabilize foam (Huppertz, 315 2010).

\section{3. Conclusion}

317 Variations in functional and surface properties of the two TPP fractions are due to 318 several factors (heat treatments, UHT or whey processing), extraction source, extraction 319 method and the composition of each fraction (lipids and proteins). Milk TPP exhibited a 320 higher surface activity and a better monolayer film resistance to mechanical disturbances. 321 Whereas the best foaming properties were exhibited by WPC TPP. This best performance of 322 WPC TPP compared to milk TPP is due to the lipid fraction of milk TPP which prevents them 323 to foam. It is conceivable they could both be used as surface-active agents in food 324 applications requiring foam formation. On the other hand, the extraction from WPC would be 325 interesting because it is advantageous in terms of high TPP production yield and economical 326 compared to TPP extracted from milk. 


\section{References}

Albrecht, O., and Sackmann, E. (1980). A precision Langmuir film balance measuring system. Journal of Physics E: Scientific Instruments, 13(5), 512-515.

Andrews, A. T. (1983). Proteinases in normal bovine milk and their action on caseins.

Journal of Dairy Research, 50(1), 45-55.

Association of Official Analytical Chemists International. 2000. Official Methods for Analysis. Fat in milk (modified mojonnier method)-method 989.05; 33.2.26, ash of dried milk method 930.30; 33.5.05. AOACI $17^{\text {th }}$ edn, Gaithersburg, MD.

Baglioni, P., Gabrielli, G., Guarini, G. T. (1980). On the mechanism of collapse of monolayers of macromolecular substances II. Cellulose acetate. Journal of Colloid and Interface Science, 78(2), 347-355.

Bastiaens, A., Paquot, M., Marbaise, M., Deroanne, C. (1990). Foaming capacity of protein isolates: effect of the electro-kinetic potential of protein dispersions. Sciences des aliments, 10(4), 773-783.

Blecker, C., Anceau, C., Danthine, S., Deroanne, C., Laloux, J., Sindic, M., Van Reusel, A. (2005). S'adapter aux exigences du marché, innover dans les productions animales et maîtriser la qualité. Cas du lait et de la viande. Communication orale « Dixième Carrefour des Productions Animales », Gembloux, Belgique, 26 janvier 2005.

Boyd, J. V., Mitchell, J. R., Irons, L., Musselwhite, P. R., Sherman, P. (1973). The mechanical properties of milk protein films spread at the air-water interface. Journal of Colloid and interface Science, 45(3), 478-486.

Blecker, C., Paquot, M., Lamberti, I., Sensidoni, A., Lognay, G., and Deroanne, C. (1997). Improved emulsifying and foaming of whey proteins after enzymic fat hydrolysis. Journal of Food Science, 62(1), 48-52/74. 
Brnčić , M., Bosiljkov, T., Ukrainczyk, M., Tripalo, B., Rimac Brnčić, S., Karlović, S., Karlović, D., Ježek, D., Vikić Topić, D. (2011). Influence of whey protein addition and feed moisture content on chosen physicochemical properties of directly expanded corn extrudates. Food and Bioprocess Technology, 4(7), 1296-1306. DOI 10.1007/s11947-009-0273-0.

Cassiani, D. M., Yamul, D. K., Conforti, P. A., Pérez, V. A., Lupano, C. E. (2011). Structure and functionality of whey protein concentrate-based products with different water contents. Food and Bioprocess Technology, DOI 10.1007/s11947-011-0680-x.

Dagorn-Scaviner, C. (1986). Etudes des proprieties tensioactives des gliadines du pois. Application aux isolats protéiques utilisés comme agents d'émulsification ou de moussage. Thèse de Doctorat, Université de Nantes.

Gaines, G. L. (1966). Insoluble Monolayers at Liquid-gaz Interface. Prigogine, Interscience, New York, p 1-386.

German, J. B., O’Neil, T. E., Kinsella, J. E. (1985). Film forming and foaming behavior of food proteins. Journal of the American Oil Chemists'Society, 62(9), 1358-1366.

Girardet, J. M., and Linden, G. (1995). PP3 component of bovine milk: a phosphorylated whey glycoprotein. Journal of Dairy Research, 63(2), 333-350.

Huppertz Thom. (2010). Foaming properties of milk: A review of the influence of composition and processing. International Journal of Dairy Technology, 64(4), 477-488.

Inagaki, M., Nakaya, S., Nohara, D., Yabe, T., Kanamaru, Y., Suzuki, T. (2010). The multiplicity of n-glycan structures of bovine milk $18 \mathrm{kDa}$ lactophorin (milk glyCAM-1). Bioscience: Biotechnology and Biochemistry, 74(2), 447-450.

Innocente, N., Corradini, C., Blecker, C., and Paquot, M. (1998a). Dynamic surface properties of the proteose-peptone fraction of bovine milk. Journal of Dairy Science. 81(7), $1833-1839$. 
Innocente N., Corradini C., Blecker C., and Paquot M. (1998b). Emulsifying properties

of the total fraction and hydrophobic fraction of bovine milk proteose-peptone. International

Dairy Journal. 8(12), 981-985.

Innocente, N., Biasutti, M., and Blecker, C. (2011). HPLC profile and dynamic properties of the proteose-peptone fraction from bovine milk and whey protein concentrate. International Dairy Journal, 21(4), 222-228.

Kamikaze, N., K., K., Gonçales, M., M., Zaia, C., T., B., V., Zaia, D., A., M. (2003). Determination of total protein in cow milk powder sample s: a comparative study between the Kjeldahl method and spectrophotometric methods. Journal of Food Composition and Analysis, 16(4), 507-516.

Kanno, C., 1989. Purification and separation of multiple forms of lactophorin from bovine milk whey and their immunological and electrophoresis properties. Journal of Dairy Science., 72(4), 883-891.

Kollar, C. K., and Brunner, J. R. (1970). Proteose-peptone fraction of bovine milk: lacteal serum component 5 and 8 casein associated glycoprotein. Jouranl of Dairy Science. 53(8), 997-1008.

Lowry O. H., Rosebrough N. J., Farr A. L., and Randall R. J. (1951). Protein measurement with the folin phenol reagent. Journal of Biological Chemistry. 193, 265-275.

Mati, A., Girardet, J. M., Xenakis, D., Linden, G. (1991). Isolement et Caractérisation de la fraction hydrophobe des Protéose-peptones des laits Bovin, Ovin et Caprin. Lait, 71(3), $259-273$

Pâquet, D., Nejjar, Y., \& Linden, G. (1988). Study of hydrophobic protein fraction of isolated from milk proteose-peptone. Journal of Dairy Science, 71(6), 1464-1471.

Pâquet, D. (1989). Review: The proteose-peptone fraction of milk. Milk, 69(1), 1-21. 
Paris, p 184.

Rodriguez-Patino and De la Fuente Feria. (1995). Destabilization of monogleceride monolayers at the air-water interface: structure and stability relationships. In: Food Macromolecules and Colloids, The Royal Society of Chemistry, Cambridge, eds. E. Dickson, and D. Lorient, p 109-113.

Nakai, S., Ho, L., Kato, A., Tung, M. A. (1980). Relationships between hydrophobicity and emulsifying properties of some plant proteins. Canadian Institute of Food Science Technology Journal, 13, 23-27.

Schägger H. (2006). Tricine-SDS-PAGE. Nature. Publishing Group. 1(1). 16-22.

Sorensen, E. S., \& Petersen, T. E., 1993. Purification and characterization of three proteins isolated from the proteose-peptone fraction of bovine milk. Journal of Dairy Research., 60(2), 189-197.

SPSS Inc. (1999). SPSS. Chicago:SPSS.

Shimizu, M., Yamauchi, K., Saito, M. (1989). Emulsifying properties of the proteosepeptone fraction obtained from bovine milk. Milchwissenschaft, 44(8), 497-500.

Zhu, H., and Damodaran, S. (1994). Proteose Peptones and Physical Factors Affect 417 Foaming Properties of Whey Protein Isolate. Journal of Food Science, 59(3), 554-560. 


\section{List of Tables}

Table 1: Composition, expressed in percentage of dry material, of powders of total proteosepeptone fractions extracted from WPC and milk.

Table 2: Equilibrium surface pressure $\left(\pi_{\mathrm{e}}\right)$ and Initial adsorption rate $(\mathrm{V})$ at air-water interface for total proteose-peptone fractions at $1 \%(\mathrm{w} / \mathrm{w})$ of protein at various $\mathrm{pH}$.

Table 3: Maximum elasticity value of total proteose-peptone fractions films at various $\mathrm{pH}$.

Table 4: Speed of decreasing $\left(\mathrm{cm}^{3} \cdot \mathrm{min}^{-1}\right)$ after switching off the bubbling of total proteosepeptone fractions foams at $1 \%(\mathrm{w} / \mathrm{w})$ at various $\mathrm{pH}$.

\section{List of Figures}

432 Figure 1: Tricine-SDS-PAGE electrophoresis of proteose-peptones fractions, WPC and milk. 433 M: Marker, I: WPC, II: Residual WPC after TPP extraction, III: WPC TPP, IV: Milk TPP and 434 V: Milk protein.

435 Figure 2: Surface tensions as a function of time for $1 \%$ of total proteose-peptone fractions 436 (Milk TPP ( $\bullet$ ) and WPC TPP (o)) using the drop volume method. (A) pH 4.0, (B) native pH, 437 and (C) $\mathrm{pH} 7.0$.

438 Figure 3: Isotherms of compression of total proteose-peptone fractions ( - Milk TPP) and (439 WPC TPP) monolayers spread on aqueous solutions at (A) $\mathrm{pH} 4.0$, (B) native $\mathrm{pH}$ and (C) $\mathrm{pH}$ 440 7.0. Registered at $25 \pm 0.5^{\circ} \mathrm{C}$. Spread $50 \mu \mathrm{L}$ of solution. Average of three repetitions.

441 Figure 4: Foaming capacity at various pH of total proteose-peptone fractions $1 \%$. ( $\bullet$ ) Milk 442 TPP and (o) WPC TPP at various $\mathrm{pH}$.

443 Figure 5: half-life of the foam related to various $\mathrm{pH}$ of total proteose-peptone fractions at $1 \%$ 444 (w/w): (•) Milk TPP and ( o) WPC TPP.

445 Figure 6: Evolution of total proteose-peptone fractions foam ( Milk TPP) and (० WPC TPP) 446 at $1 \%(\mathrm{w} / \mathrm{w})$ over time $(450 \mathrm{~s})$ at $(\mathrm{A}) \mathrm{pH} 4.0,(\mathrm{~B})$ native $\mathrm{pH}$ and $(\mathrm{C}) \mathrm{pH} 7.0$. 


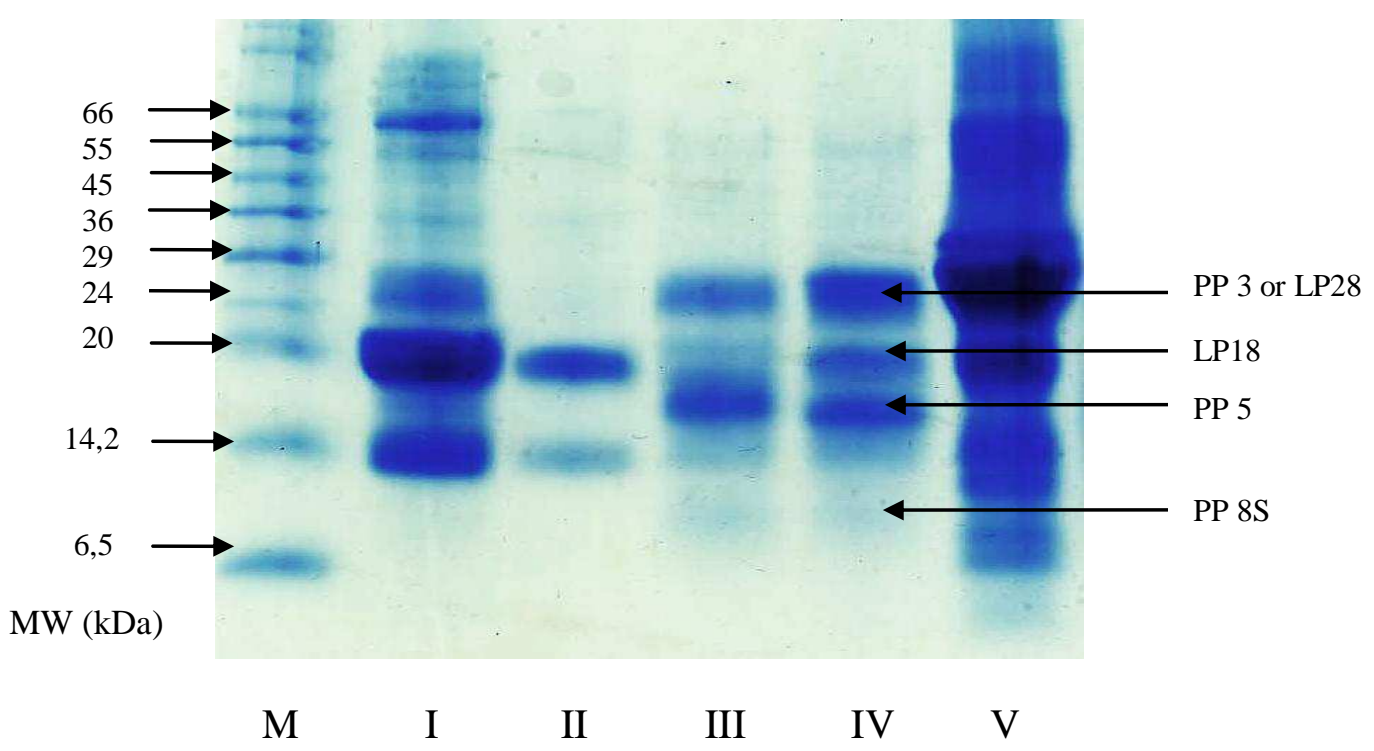

Figure 1: Tricine-SDS-PAGE electrophoresis of proteose-peptones fractions, WPC and milk. M: Marker, I: WPC, II: Residual WPC after TPP extraction, III: WPC TPP, IV: Milk TPP and V: Milk protein. 

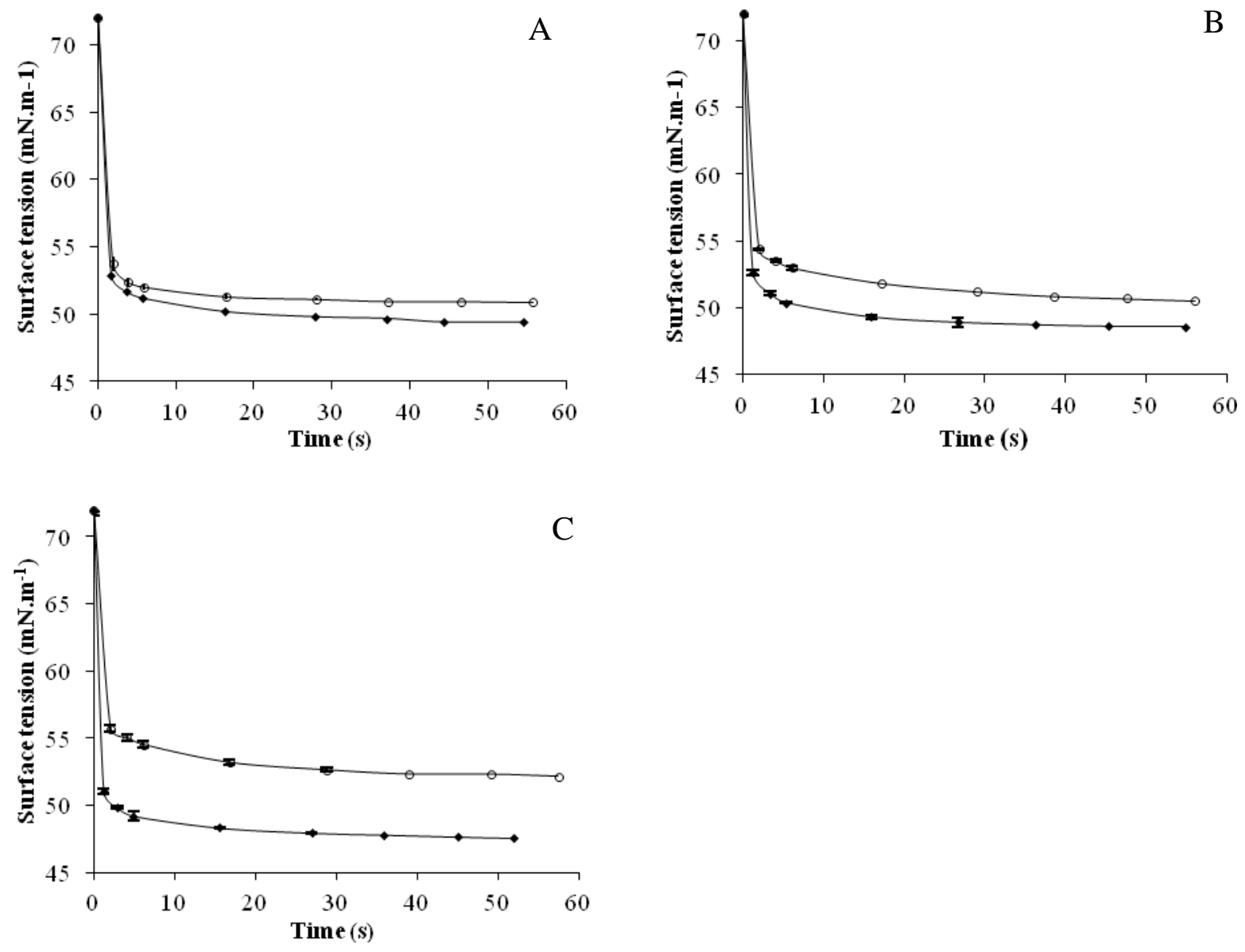

Figure 2: Surface tensions as a function of time for $1 \%(\mathrm{w} / \mathrm{w})$ of total proteose-peptone fractions (Milk TPP ( ) and WPC TPP (o)) using the drop volume method. (A) $\mathrm{pH} 4.0$, (B) native $\mathrm{pH}$, and (C) $\mathrm{pH}$ 7.0. 


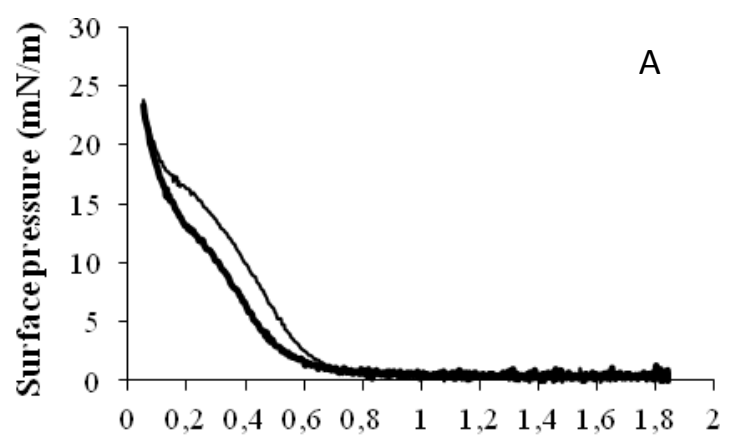

Surface area $\left(\mathrm{m}^{2} / \mathbf{m g}\right)$

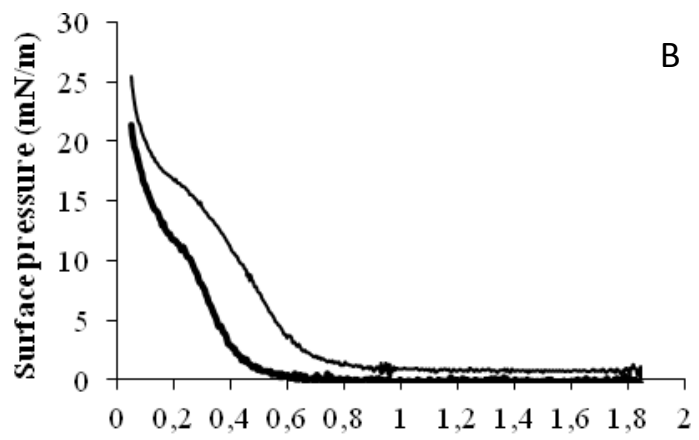

Surface area $\left(\mathbf{m}^{2} / \mathbf{m g}\right)$

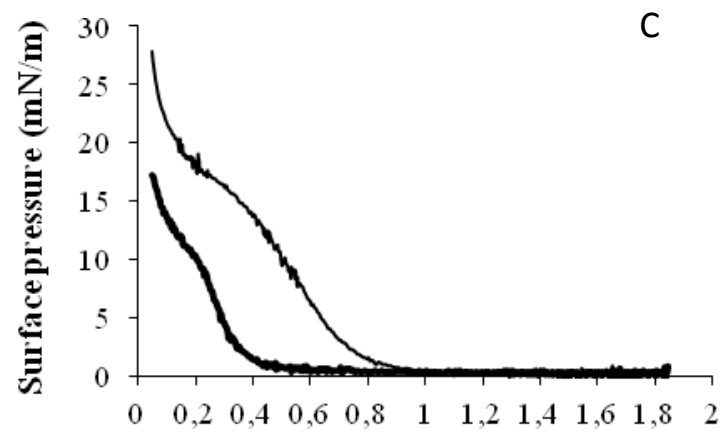

Surface area $\left(\mathrm{m}^{2} / \mathbf{m g}\right)$

Figure 3: Isotherms of compression of total proteose-peptone fractions ( Milk TPP) and ( WPC TPP) monolayers spread on aqueous solutions at (A) $\mathrm{pH} 4.0$, (B) native $\mathrm{pH}$ and (C) $\mathrm{pH}$ 7.0. Registered at $25 \pm 0.5^{\circ} \mathrm{C}$. Spread $50 \mu \mathrm{L}$ of solution. Average of three repetitions. 
Click here to download Figure: Figure 4.doc

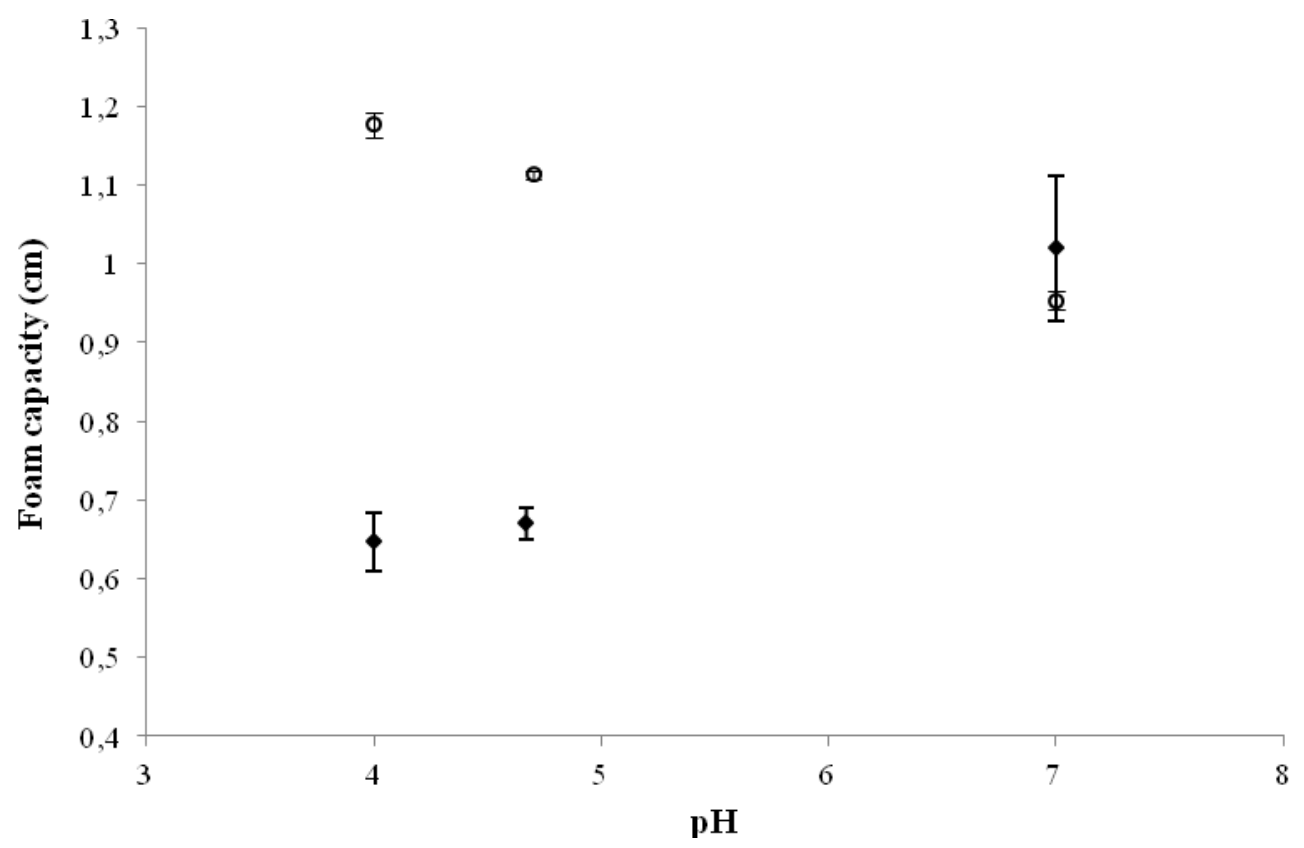

Figure 4: Foaming capacity at various $\mathrm{pH}$ of total proteose-peptone fractions $1 \%$. ( ) Milk TPP and (o) WPC TPP at various $\mathrm{pH}$. 
Click here to download Figure: Figure 5.doc

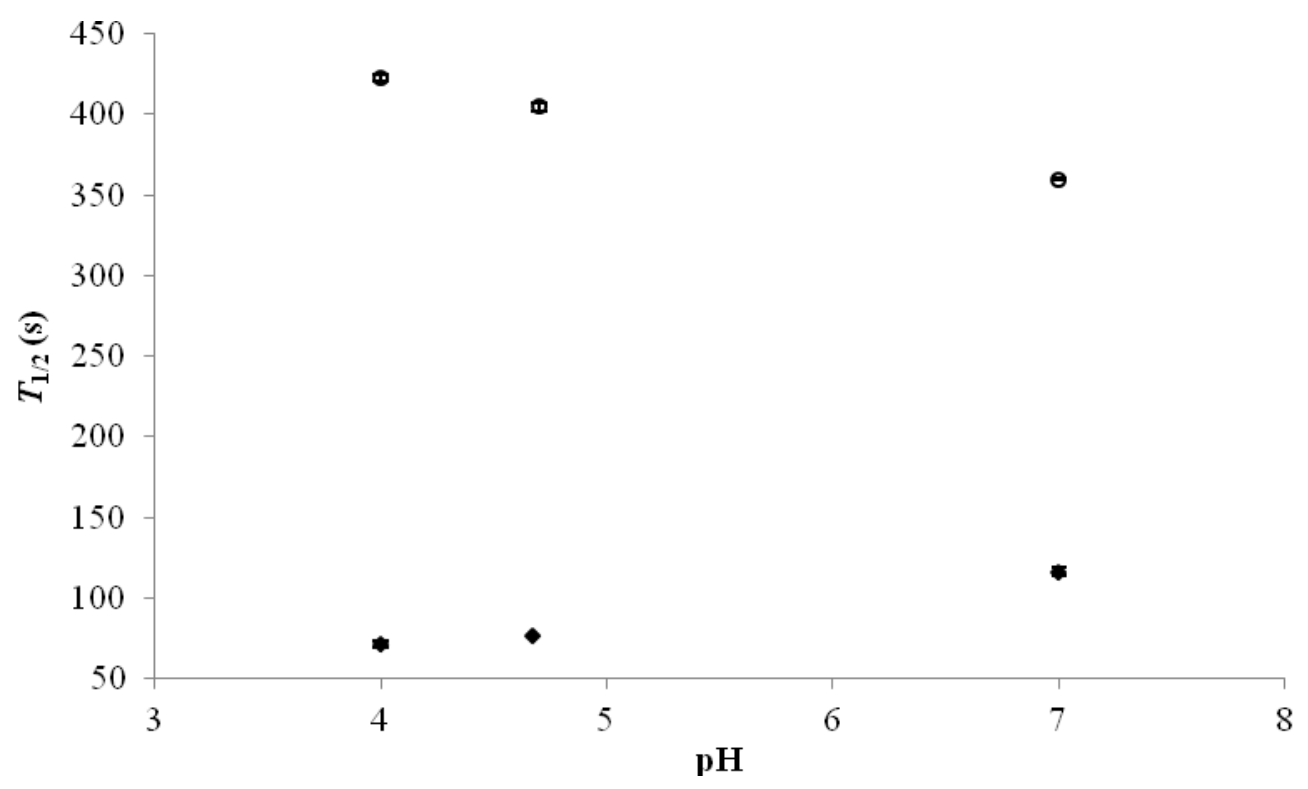

Figure 5: half-life of the foam related to various $\mathrm{pH}$ of total proteose-peptone fractions at $1 \%$ : $(\bullet)$ Milk TPP and ( o) WPC TPP. 

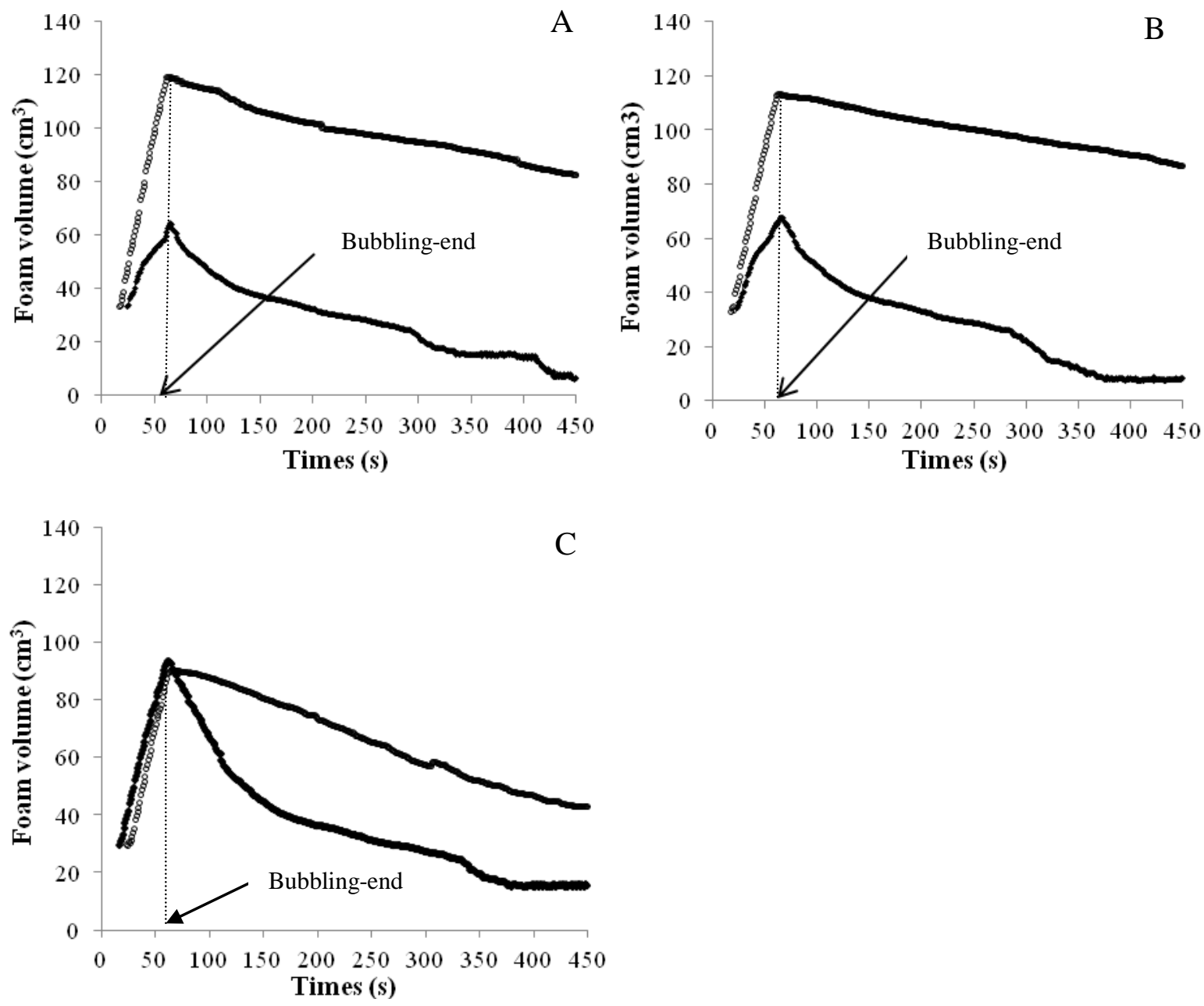

Figure 6: Evolution of total proteose-peptone fractions foam ( $\bullet$ Milk TPP) and ( oWPC TPP) at $1 \%$ (w/w) for the first 450s at (A) $\mathrm{pH} 4.0,(\mathrm{~B})$ native $\mathrm{pH}$ and (C) $\mathrm{pH} 7.0$. 
Table 1: Composition (\% of dry material) of freeze dried TPP fractions extracted from WPC and milk.

\begin{tabular}{lccc}
\hline & WPC TPP & & Milk TPP \\
\cline { 2 - 3 } Protein & (Dry matter : $91.40 \% \pm 0.04)$ & & $($ Dry matter : $91.75 \% \pm 0.10)$ \\
Ash & $65.20 \% \pm 0.03^{\mathrm{a}}$ & $79.15 \% \pm 0.10^{\mathrm{b}}$ \\
Lipid & $3.50 \% \pm 0.15^{\mathrm{a}}$ & $2.85 \% \pm 0.13^{\mathrm{a}}$ \\
Lactose & $4.60 \% \pm 0.08^{\mathrm{a}}$ & $6.55 \% \pm 0.05^{\mathrm{b}}$ \\
\hline
\end{tabular}

${ }^{\text {a }}$ Values within the same line followed by the same superscript letters do not differ significantly at $\mathrm{P}<$ 0.05 (Duncan test). Mean of triplicates. 
Table 2: Equilibrium surface pressure $\left(\pi_{\mathrm{e}}\right)$ and Initial adsorption rate $(\mathrm{V})$ at air-water interface for total proteose-peptone fractions at $1 \%(\mathrm{w} / \mathrm{w})$ of protein at various $\mathrm{pH}$.

\begin{tabular}{cccc}
\hline & $\mathrm{pH}$ & $\mathrm{V}\left(\mathrm{mN} \cdot \mathrm{m}^{-1} \cdot \mathrm{s}^{-1}\right)$ & $\pi_{\mathrm{e}}\left(\mathrm{mN} \cdot \mathrm{m}^{-1}\right)$ \\
\hline & 4.00 & $11.39 \pm 0.12^{\mathrm{d}}$ & $23.39 \pm 0.24^{\mathrm{d}}$ \\
& 4.67 & $15.60 \pm 0.15^{\mathrm{e}}$ & $24.11 \pm 0.03^{\mathrm{e}}$ \\
\hline & 7.00 & $17.37 \pm 0.19^{\mathrm{f}}$ & $24.88 \pm 0.12^{\mathrm{f}}$ \\
\hline & 4.00 & $9.61 \pm 0.18^{\mathrm{c}}$ & $21.66 \pm 0.09^{\mathrm{c}}$ \\
\hline
\end{tabular}

${ }^{\text {a }}$ Values within the same column followed by the different superscript letters are differ significantly at $\mathrm{P}<0.05$ (Duncan test). Mean of triplicates. 
Click here to download Table: Table 3.doc

Table 3: Maximum elasticity value ( $\epsilon)$ of total proteose-peptone fractions films at various $\mathrm{pH}$.

\begin{tabular}{|c|c|c|}
\hline & $\mathrm{pH}$ & $\epsilon\left(\mathrm{mN} \cdot \mathrm{m}^{-1} \cdot \mathrm{s}^{-1}\right)$ \\
\hline \multirow{3}{*}{ 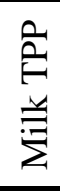 } & 4.00 & $10.19 \pm 0.01^{b}$ \\
\hline & 4.67 & $10.22 \pm 0.27^{\mathrm{b}}$ \\
\hline & 7.00 & $11.62 \pm 0.12^{c}$ \\
\hline \multirow{3}{*}{$\begin{array}{l}\hat{2} \\
\hat{E} \\
\vdots \\
3\end{array}$} & 4.00 & $13.15 \pm 0.09^{\mathrm{e}}$ \\
\hline & 4.70 & $12.32 \pm 0.14^{\mathrm{d}}$ \\
\hline & 7.00 & $9.05 \pm 0.09^{\mathrm{a}}$ \\
\hline
\end{tabular}

${ }^{a}$ Values within the same column followed by the same superscript letters do not differ significantly at $\mathrm{P}<0.05$ (Duncan test). Mean of triplicates.

$\epsilon=-\mathrm{A}(\mathrm{d} \pi / \mathrm{dA})$. 
Table 4: Speed of decreasing $\left(\mathrm{cm}^{3} \cdot \mathrm{min}^{-1}\right)$ after switching off the bubbling of total proteose-peptone fractions foams at $1 \%(\mathrm{w} / \mathrm{w})$ at various $\mathrm{pH}$.

\begin{tabular}{ccc}
\hline & $\mathrm{pH}$ & Speed of decreasing $\left(\mathrm{cm}^{3} \cdot \mathrm{min}^{-1}\right)$ \\
\hline & 4.00 & $8.84 \pm 0.72$ \\
& 4.67 & $9.16 \pm 1.06$ \\
& 7.00 & $12.06 \pm 1.55$ \\
\hline
\end{tabular}

Means of triplicates. 


\begin{abstract}
Total proteose-peptone (TPP) fractions were extracted from skimmed milk (UHT) and whey protein concentrate (WPC) on a laboratory scale. Protein solutions $(0.1,0.5$ and $1 \%$ w/w) were characterized as function of $\mathrm{pH}$ : 4.0, 4.6-4.7 (native $\mathrm{pH}$ ) and 7.0. Their foaming capacities and stabilities were studied. Beforehand, the surface properties that govern them were investigated, notably the kinetics of adsorption and mechanical properties of monolayer films at the air-water interface involved in the formation and the stability of foams respectively. The TPP extracted from skimmed milk showed the lowest values as well as a significant reduction in surface tension and presented a good mechanically resistant film. The TPP extracted from WPC presented a better foaming capacity and stability which was unexpected. However, foaming properties and surface properties of TPP fractions depended on the $\mathrm{pH}$. The considerable influence of extraction source and method on proteose-peptone's properties were highlighted.
\end{abstract}

